\title{
Necessity and problems of formation of alternative paradigm of the development of accounting science
}

\author{
Vita Semanyuk * \\ PhD in Economics, Associate Professor, Postdoctoral Student of the Department of Audit and Analysis \\ Ternopil National Economic University, Lvivska Street, 10, 46-009, Ternopil, Ukraine \\ *Corresponding authorE-mail:v.semaniuk@tneu.edu.ua
}

\begin{abstract}
The main research objective is to develop the theory of accounting for the conditions of forming post-industrial society solving research tasks, which concern the concept of accounting system of post-industrial type and the development of its main attributes. What will support the development of general theory and reveal accounting as a system of creating information resources at macroand micro-levels. It will reflect the main principles and tasks of accounting in the light of modern development of economy, investigate the structure, elements and connections of the system, and define tasks, instruments and methods of each of subsystems of accounting.
\end{abstract}

Keywords: Accounting System; Post-industrial Society; Management Accounting; Financial Accounting; Strategic Accounting; Management System; Management Requests; Information Resources.

\section{Introduction}

Fundamental changes in the system of socially-economic relations of post-industrial society cause the necessity of profound investigation of modern condition of the science about accounting. Economic science is in progress under the influence of public development and requires from the system of accounting taking into consideration achievement so further sciences, borrowing and developing new methods of creating information. There is the necessity to define a new content of accounting theory and the development of its methods and instruments, emphasize new types of accounting and objects of observation to get information in the system of reporting for different groups of users. However, the existing theory of accounting as the base on the development of the accounting system is too conservative and imperfect; it does not consider modern conditions of functioning of economic subjects. It does not use the latest achievements of science. It almost does not differ from the theory of the nineteenth century. The absence of proper theoretical grounds of accounting as a science causes the slowdown of innovative approaches to the accounting system, makes accounting as "technical operations," veils the purpose and subject of the science, prevents improvement of its methods. An alternative paradigm of the development of accounting should be formed during the light of the philosophy of the science and research methods, including social, ecological and economic processes and their problems. Institutional and social aspects, professional ethics, culture, human resources and intellectual capital, changes of prices, transactional and insider operations, global processes and processes of standardization and not traditional objects of accounting should be taken into consideration in formation of accounting theory.

\section{Methodology/methods}

The hypothesis about that the theory of accounting is the base of the science about accounting is the basis and output data for the investigation. Accounting is represented as the system having three subsystems: managerial accounting (information at operational level), financial accounting (information at tactical level) and strategic accounting (information of strategic character). General scientific methods and philosophical means of perception, methods of classification and systematization, modelling, content analysis etc will be used for solving problems of systematization of knowledge and review of modern theory of accounting taking into consideration achievements of economic and technological progress.

\section{The presentation of the main ideas}

Modern achievements of economic theory state that the economy of the $21^{\text {st }}$ century is based on the knowledge and innovations, which are materialized in the form of new high effective scientific technologies and products. The analysis of the concept of "the economy of knowledge" and the definition of its main postulates need to be profoundly investigated considering the interconnection with modern economic concepts.

In P. Drucker's opinion, modern economy is "the economy of knowledge, "the sphere of production and information dissemination - "the industry of knowledge," and all society is "the society of knowledge" (Drucker, Peter, 1974). In other words, only knowledge creates productivity nowadays, and it is the base for the economic growth but not old factors of production. The forming and development of "the economy of knowledge" or "the society of knowledge" predicts free automated access to any infor- 
mation and knowledge, which are necessary for vital activity and solving of individual and socially important tasks; accessibility (for a person, group, organization) to modern information technology; existing of developed infrastructure supporting creating information resources.

Accounting system under the conditions of the development of "the economy of knowledge" should become not only the system of statement of facts about the financial state of business entity, but it should be transformed to the system of monitoring and creating information resources for management. Modern information paradigm in accounting provides the processes of knowledge with the range of essential features and tendencies, one of which is connected with information processes, which require the understanding at the general theoretical and specifically scientific level Many issues connected with information resources, in fact, are starting to be used in scientific world and specific presentation of a problem about the qualitative assessment of these resources, and their connection with other economic categories should be developed by common efforts of specialists and scholars in different spheres of knowledge.

The theory of accounting adapting to new standards of "the new economy" should be changed. The concept of information and information resources from the position of the semantic and content aspects should be reinterpreted. Informational constraint, ineffective use of technology, disbalance concerning receiving information not including its value, what causes difficulties to manage it can be observed in the modern accounting system. M. Pushkar states that sensible goal of accounting is a system projecting generating information that becomes a strategic resource in post-industrial society (Pushkar M, 2006, 2007). If the accounting system is the main information generator for management, then information and information resources should be studied in the theory of accounting. There are the following tasks in the accounting system: adaptation to new conditions, the growth of information content, its importance for management, reinterpretation of its role and content in modern society requiring improvement of forms and methods of accounting.

In accounting, the concept of information should be adapted to economic activity of business entity and therefore, we suggest considering information (knowledge), which is strategic and involved in productive-commercial activity, taking decisions and study as information resources. The theory of accounting should show its relations with information resources, their non-material form and consider them as an object and product of accounting. We can find a lot of good investigations done in the theory of accounting, but they are fragmentary, and materials in textbooks are similar to previous editions. Integral and basic research giving theoretical concepts about accounting in modern society, its tasks, methods and instruments can hardly be found in Ukraine. The full discrepancy between the concepts "theory," which should reveal philosophical categories of the process of perception at the highest level and explain the reflection of the reality, and reproduction in logics the concepts of objective reality and modern interpretation of the science about accounting can be observed.

Scientific investigations in the sphere of accounting are mainly directed to the reforming of its practice and forecasting the tendencies of the development. Altogether, the issues about the development of the theory of accounting are insufficiently investigated, as it was emphasized by Professor M. Pushkar, and they are "primitive trivial set of separate fragmentary, almost not interconnected and not reasoned procedures of accounting, which are famous since the Middle Time and pretend to be the theory," [1, P.5].The theory of accounting is not improved according to the development of economic science. It does not form a new approach to traditional categories. It does not use achievements of classical accounting theories, and each of them is unique and contains possibilities for the development of new scientific directions. Transition to post-industrial society causes the necessity of creating a new system of management and adequate system of accounting. Effective system of accounting can not satisfy information needs of users, investors, creditors, managers and other users be- cause of its limitedness, that is why the current problem is reorientation of accounting to the needs of management.

General fundamental problem, which should be solve disconservative character of the theory of accounting and its discrepancy in the development of economic science and public formations; concrete fundamental task within general problem is improvement (development) of alternative theory taking into consideration all factors of post-industrial society.

Under the conditions of the rapid social development, the interpretations and definitions of accounting, which we can read in modern textbooks in the theory are insufficient: "Accounting is quantitative reflection and qualitative characteristic of economic activity to manage it" (it is free definition because all definitions have really the same content). The definition of accounting should reveal all aspects as a system, show accounting not only as a function of management but also as a science, an object to the law, an element of the social, economic and public system. However, because of absence of profound theoretical base of the system of accounting and its subsystems, different understanding of the same concepts, categories and even objects of accounting can be observed.

Therefore, from the position of modern institutional approach, the theory of accounting should be reinterpreted considering the achievements of economic and other sciences. Modern theory should study accounting as a system and investigate it in the light of macroeconomics, microeconomics, law, taxation, social and corporate responsibility, ethics, behaviourism, etc.

We suggest interpreting accounting as the system of creating economic information about the light of three subsystems - management accounting, financial accounting, strategic accounting - with the definition of tasks of these subsystems, principles of their functioning, instruments and methods of investigation of each subsystem. Accounting is the science, which is formed under the influence of socially-economic factors and satisfies the need of society in information about economic and other activity of business entities; as a social phenomenon, it is formed through the influence of social development having some impact on the society.

So-called modern theory of accounting defines it as a set of instruments for processing of some economic information, alternative approach should present the theory of accounting as a theoretical base of the science about accounting with philosophical approach and conceptual statement.

To achieve this goal, the following tasks should be solved:

- To investigate modern theory of accounting and fins ways of its improvement for the possibilities of further development of the science of accounting science;

To define the place of accounting as the science in the system of economic sciences;

To define the factors of influence in the development of the theory of accounting;

To reveal the reasons of origin of the science of accounting to understand its modern state and evaluate possible directions of the development;

To study the development of the science of accounting in the countries of Anglo-American world in the $20^{\text {th }}$ century to find principles, organization and legal base and investigate accounting as a social phenomenon;

To present accounting as the system with correspondent division into subsystems and prove the necessity of their existence and development;

To investigate and define the structure of the theory of accounting, its elements and relations between them;

Toinvestigatetheissueoftraditionalfinancialaccountinginthreeaspects: definition, recognition and assessment;

To prove the necessity of development additional forms of revealing the financial information of business entity reporting according to segments, reports about added value, financial forecasting of corporations and accounting of trademarks; 
- $\quad$ To form the principles of accounting of human resources and intellectual capital, to develop the procedure of development and implementation of the system of accounting of such resources;

- To reveal the essence and concept of "creative accounting";

To study the subject of professional ethics and its development in the light of change of professional relations between accountants and society, and the impact of culture as an important element of the world around on accounting;

To define the necessity and order of creating and presentation of the system of not financial reporting;

To define the possibilities of accounting as a social phenomenon having the impact on social development.

The essence of adequate theory of accounting to get new knowledge, hypotheses, theories and further implementation depends on the development of the alternative theory of accounting, which will promote the development of the science of accounting, remove all discrepancies and contradictions between tasks and methods of accounting systems, their role and meaning for information support of management.

Without improvement of theoretical base and bringing it in balance with correspondent socially-economic realities, the science of accounting can not be improved, and it will not support users with relevant information and the process of management will be without accurate information base. There is the necessity in innovative approach in the theory of accounting, development of new theoretical concept, which would investigate accounting as the system with all consequences and its characteristics as a system consisting of subsystems, and each of them has its tasks, methods and instruments of their solution. There is the necessity for the development of the structure of accounting, the definition of its elements and relations between them. The approach to the theory of accounting as a science (the system of knowledge) about methods and instruments of creating information and new approach to the system of reporting considering information requires of all users, especially foreign (including the society) are necessary. The idea about a socially-economic role of accounting and its meaning should be the base of the innovative approach to the theory of accounting.

Unfortunately, in Ukraine, Research and Development Institutes and higher educational establishments pay insufficient attention to the theoretical problems with the development of accounting science, and experts consider the existing theory to be the pink of perfection.

The development of the theoretical base of accounting science considering all factors having an impact on it under the conditions of information society will support the development of the integral theory of accounting, which will define its object and subject, place within the system of economic sciences, relations with other sciences, meaning for the society, etc. It will present accounting as a science about methods of creating information and information support of all users considering the latest findings in systems science, cybernetics, management, informatics, mathematics, philosophy, logics, psychology, etc.

Study of accounting requires understanding it as a system having system features and consisting of separate subsystems (financial, management, strategic accounting). The grounds of each of these types of accounting and study of its methods, new approach to development of the system of reporting considering social, ecological, marketing, technical and other factors influencing the system of accounting are required in study of accounting.

The base of the theory of accounting in information society is knowledge about the following factors:

- Philosophy and methods of the science about accounting;

- Classification and verification of theories of accounting: normative and positive theory;

- Innovative aspects of financial accounting and reporting;

- Principles and standards of accounting for the conditions of information dynamics;
- Problematic issues concerning traditional financial accounting: definition, recognition and assessment of the main objects of accounting and non-traditional objects of accounting;

- The theoretical viewpoint of the system of accounting under the conditions of inflation and changes of prices;

- Systems and forms of disclosure (data submission) of financial information;

- Non financial reporting, its necessity, role, meaning and methods of creating under the conditions of information society;

- Modelling and models in the theory of accounting;

- Problems of harmonization and diversification in accounting;

- Professional ethics, culture, accounting values;

- Social role of accounting in information society and accounting as a social phenomenon.

\section{Findings}

Traditional system of accounting does not satisfy users' information needs, and this system needs to be improved in the part of adaptation of the theory of accounting to modern scientific findings in economic realm and the development of society. The science about accounting can not develop and satisfy users providing relevant information without improvement of the theoretical base and its arrangement according to social and economic realities, and the management process will have not been accurate information base. Author suggested a new theoretical conception, which interprets accounting as the system consisting of subsystems (financial, managerial and strategic accounting) and each of them has its tasks, methods and instruments of their solving. The idea about its social and economic role and meaning was taken as the base of innovative approach to the theory of accounting. The problems with the development of the theory of accounting were investigated in the light of philosophy of the science and the research methods considering historical and social processes. Accounting as the science about methods of creating information and information support of all users considering the latest findings of systems science, cybernetics, management, informatics, mathematics, philosophy, logics, psychology, etc. was represented in the article.

\section{Conclusions}

Accounting is the science, which is formed through the influence of social and economic factors and satisfies the need of society in information about economic and other activity of business entity. Accounting has some impact on society. Therefore, the urgent problem is to form alternative paradigm considering scientific approaches to the method of accounting science in the light of philosophy of science - induction and deduction, falsification, paradigm and philosophical approaches of K. Popper, T. Kuhn, I. Lakatos, P. Feyerabend, L. Wittgenstein, N. Wiener, S. Beer, B. Gates and other authors.

To present accounting as a science with the profound theoretical base, the methods and principles of building accounting as a system should be developed. Conceptual models of all subsystems of accounting (financial, management, strategic) should be formed; the essence of the main institutions in accounting should be revealed; the ways of solving problems should be grounded; the content of the theory of accounting considering the modern philosophy of post-industrial society should be improved.

The prospects of further investigations are the following: to find possibilities to develop accounting as a science of the conditions of information society and within the context of knowledge implementation into practice by subjects of business entities using the relevant information, which corresponds to economic realities and considering the effectiveness of taking management decisions. 
The integral theory of accounting will give the opportunity for students of higher educational establishments to integrate, systematize and receive the system of knowledge, and it will support the development of scientific investigations concerning problems of improvement of the accounting system.

\section{References}

[1] Pushkar M. (2007) Metatheory accounting or what should be the theory. Kart-blansh, Ternopil, Ukraine. 359 p.

[2] Holov S. (2007) Accounting in Ukraine: analysis and prospects of its development. Tsentr uchbovoi literatury, Kyiv, Ukraine. 522 p.

[3] Kuznetsova S. (2007) Accounting in the system of management information: Methodology and Practice. Taurian State Agrotechnical University, Melitopol, Ukraine. 297 p.

[4] Pylypenko A. (2011) Formation of accounting and analytical software cost management of enterprises and their associations, KhNUE, Kharkiv, Ukraine. 344 p.

[5] Pushkar M. (2006) Creative accounting: creating information for managers. Kart-blansh, Ternopil, Ukraine. 334 p.

[6] Ryan B. (1995) Strategic accounting for management. London: Dryden Press; 362 p

[7] Sokolov Ja. (1996) Theory and History of Accounting. Moskva: Audyt YUNYTY. 638p.

[8] Kuter M. (2004) Theory of Accounting. Moskva: Finansy i statystyka. 640 p.

[9] Palyj V. (1988) Theory of Accounting. Moskva: Finansy i statystyka. 279 p.

[10] Semanyuk V. (2009) Forming of New Types of Accounting and Prospects of Their Development. Ternopil: The HERALD of Ternopil National Economic University, Issue 3, Ukraine. pp. 112-116 [http://library.tneu.edu.ua/images/stories/naukovi\%20zhurnaly/visn yk\%20tneu/2009/3-2009_v_tneu.pdf].

[11] Anwer S. A. \& Scott, D. (2013) Managerial Overconfidence and Accounting Conservatism, Journal of Accounting Research, Vol. 51 No. 1, pp.1-30.

[12] Sven Modell, Eija Vinnari, Kari Lukka (2017) on the virtues and vices of combining theories: The case of institutional and actornetwork theories in accounting research. Accounting, Organizations and Society, Volume 60, pp. 62-78. https://doi.org/10.1016/j.aos.2017.06.005

[13] Markus Granlund, Kari Lukka (2017)Investigating highly established research paradigms: Reviving contextuality in contingency theory based management accounting research. Critical Perspectives on Accounting, Volume 45, pp. 63-80 https://doi.org/10.1016/j.cpa.2016.11.003.

[14] Hans Englund, Jonas Gerdin, John Burns (2017) A structuration theory perspective on the interplay between strategy and accounting: Unpacking social continuity and transformation. Critical Perspectives on Accounting, Available online.

[15] Hans Englund, Jonas Gerdin, John Burns (2017) A structuration theory perspective on the interplay between strategy and accounting: Unpacking social continuity and transformation. Critical Perspectives on Accounting, Available online.

[16] Walker, S. P. (2016). Revisiting the roles of accounting in society. Accounting, Organizations and Society, 49, pp. 41-50

[17] Christian Axa, Jan Greve (2017). Adoption of management accounting innovations: Organizational culture compatibility and perceived outcomes. Management Accounting Research, 34, pp. 59-74 https://doi.org/10.1016/j.mar.2016.07.007.

[18] Deniz Appelbaum, Alexander Kogan, Miklos Vasarhelyi, Zhaokai Yan (2017). Impact of business analytics and enterprise systems on managerial accounting. International Journal of Accounting Information Systems, Volume 25, , pp. 29-44 https://doi.org/10.1016/j.accinf.2017.03.003.

[19] Trevor Hopper, Philippe Lassou, Teerooven Soobaroyen (2017) Globalisation, accounting and developing countries Critical Perspectives on Accounting, Volume 43, pp. 125-148 .https://doi.org/10.1016/j.cpa.2016.06.003

[20] Eve Chiapello (2017) Critical accounting research and neoliberalism. Critical Perspectives on Accounting, Volume 43, pp. 47-64. https://doi.org/10.1016/j.cpa.2016.09.002.

[21] Vera Palea (2017) Whither accounting research? A European view. Critical Perspectives on Accounting. Volume 42, pp. 59-73 https://doi.org/10.1016/j.cpa.2016.03.002.

[22] J. Baxter, W.F. (2003) ChuaAlternative management accounting research - whence and whither. Accounting, Organizations and So- ciety, 28 (2-3), pp. 97-126 https://doi.org/10.1016/S0361-3682 (02)00022-3

[23] J. Brown, J. Dillard, T. Hopper (2015) Accounting, accountants and accountability regimes in pluralistic societies: taking multiple perspectives seriously. Accounting, Auditing \& Accountability Journal, 28 (5), pp. 626-650https://doi.org/10.1108/AAAJ-03-20151996.

[24] Callen J.L. (2015) A selective critical review of financial accounting research. Critical Perspectives on Accounting, 26, pp. 157 167https://doi.org/10.1016/i.cpa.2013.03.008.

[25] Godfrey J. Hodgson A., Tarca A., Hamilton J., Holmes S. (2010) Accounting theory. (7th ed.), John Wiley \& Sons, Milton, Australia.

[26] Piketty T. (2014) Capital in the twenty-first century. Harvard University Press, Harvard. 